\title{
Endocrine responses and conception rates in fallow deer (Dama dama) following oestrous synchronization and cervical insemination with fresh or frozen-thawed spermatozoa
}

\author{
H. N. Jabbour ${ }^{1 *}$, F. A. Veldhuizen ${ }^{1}$, G. Green ${ }^{2}$ and G. W. Asher ${ }^{1}$ \\ ${ }^{1}$ Ruakura Agricultural Centre, Private Bag, Hamilton, New Zealand; and ${ }^{2}$ Winchmore Irrigation \\ Research Centre, Ashburton, New Zealand
}

\begin{abstract}
In Expt 1, 59 mature fallow deer does were allocated to six treatments $(n=9-10$ per treatment). Does assigned to treatments 1,2 and 3 each received an i.m. injection of $500 \mu \mathrm{g}$ cloprostenol on day 13 of a luteal cycle. Does in treatments 2 and 3 received 50 or 100 iu pregnant mares' serum gonadotrophin (PMSG), respectively, at the time of prostaglandin administration. Does assigned to treatments 4,5 and 6 each received single intravaginal controlled internal drug release (CIDR) devices for 14 days. Does in treatments 5 and 6 received 50 or 100 iu PMSG, respectively, at the time of CIDR device withdrawal. Incidence of oestrus was higher following treatment with CIDR devices than with prostaglandin ( 29 of 30 versus 12 of $29, P<0.001)$. PMSG induced earlier onset of oestrus $(34.6 \pm 0.9 \mathrm{~h}$ versus $44.7 \pm 2.4 \mathrm{~h}, P<0.01$ ) and reduced the range in the time to onset of oestrus (from 22 to $8 \mathrm{~h}$ for prostaglandin-treated does and from 36 to $14 \mathrm{~h}$ for progesterone-treated does). The number of LH surges was higher following treatment with CIDR devices than with prostaglandin ( 10 of 12 versus 3 of $12, P<0.01$ ). The overall mean peak $\mathrm{LH}$ concentration and time to $\mathrm{LH}$ peak were $30.2 \pm 3.4 \mathrm{ng} \mathrm{ml}^{-1}$ and $45.2 \pm 2.2 \mathrm{~h}$ after prostaglandin administration or CIDR device withdrawal. The overall median time of ovulation was $26 \mathrm{~h}$ after the onset of oestrus. The administration of 100 iu PMSG stimulated the incidence of luteinized follicles and twin corpora lutea. In Expt 2, 105 does were allocated to four treatments $(n=$ 26-27 per treatment): prostaglandin; prostaglandin with 50 iu PMSG; CIDR devices; or CIDR devices with 50 iu PMSG. The does were inseminated cervically with $200 \times 10^{6}$ frozen-thawed spermatozoa $12 \mathrm{~h}$ before the median time of ovulation as calculated for each treatment in Expt 1. The proportion of pregnant does was higher following treatment with CIDR devices than with prostaglandin (38 of 52 versus 28 of 53,P<0.05). PMSG was beneficial only for does treated with prostaglandin. In Expt 3,93 does were treated with CIDR devices for 14 days and inseminated cervically with $50 \times 10^{6}, 25 \times 10^{6}$ or $12.5 \times$ $10^{6}$ fresh spermatozoa at $12 \mathrm{~h}$ before the median time of ovulation. The concentration of spermatozoa had no effect on conception rate. The overall pregnancy rate was $76.3 \%$.
\end{abstract}

\section{Introduction}

Female fallow deer (Dama dama) exhibit a highly seasonal pattern of mating, with the onset of breeding activity in mid-late April in New Zealand (Asher, 1985). In recent years, interest in the application of controlled breeding and artificial insemination technology has grown rapidly. This has been aimed mainly at maximizing the genetic spread of superior sires (Asher et al., 1988a, 1990a; Mulley et al., 1988) with economical allocation of time and labour resources (Maxwell, 1984). Recent studies have optimized the timing of laparoscopic intrauterine insemination of fallow (Asher et al., 1988a, 1990a; Mulley et al., 1988) and

*Present address: The Zoological Society of London, Institute of Zoology, Regent's Park, London NWI 4RY, UK.

Received 27 August 1992. red (Fennessy et al., 1990) deer; conception rates in the range of $60 \%-70 \%$ are commonly achieved. However, the fertility of synchronized female deer following cervical insemination has not been satisfactory (Asher et al., 1988a; Fennessy et al., 1990; Mylrea et al., 1990). This may be related to the method of oestrous synchronization used, the timing of cervical insemination in relation to ovulation and the number of spermatozoa deposited.

In deer, oestrous synchronization can be achieved by timed withdrawal of an exogenous source of progesterone (fallow: Asher et al., 1988a, 1990a; red: Fennessy et al., 1990; chital: Mylrea ef al., 1990) or progestagen (fallow: Mulley et al., 1988; red: Kelly et al., 1982; Adam et al., 1985) or by the administration of a $\mathrm{PGF}_{20}$ analogue (Glover, 1985; Asher and Thompson, 1989; Asher et al., 1990b). In fallow deer, treatment with prostaglandin induces a more synchronous time to onset 
of oestrus than treatment with progesterone-impregnated controlled internal drug release (CIDR) devices (Asher and Thompson, 1989). However, irrespective of the form of oestrous synchronization treatment, there is less variation in the interval from the onset of oestrus or $\mathrm{LH}$ peak to ovulation than from the end of oestrous synchronization treatment to oestrus or ovulation (Asher et al., 1990b). Increased control of the onset of oestrus and consequently ovulation, and appropriate timing of insemination in relation to ovulation may be key determinants in the success of fixed-time insemination programmes.

The present study has compared the effect of six oestrous synchronization regimens on the temporal relationship between oestrus, the LH surge and ovulation in mature fallow deer during the early phase of the breeding season. Moreover, effect of the oestrous synchronization regimen and the number of spermatozoa on conception rates following cervical insemination with frozen-thawed or fresh spermatozoa at a fixed interval from the median time of ovulation was investigated.

\section{Materials and Methods}

Experiments $I$ and 2 were conducted in the South Island $\left(43^{\circ} 48^{\prime} \mathrm{E}, 17 \mathrm{I}^{\circ} 48^{\prime} \mathrm{E}\right)$ and Expt 3 in the North Island $\left(37^{\circ} 46^{\prime} \mathrm{S}\right.$, $175^{\circ} 20^{\prime} \mathrm{E}$ ) of New Zealand.

\section{Experiment 1}

Animal management and treatments. The experiment was conducted between April and May 1990 using 59 mature fallow deer does and five intact bucks. The animals were always kept in five separate groups (groups 1 to $5, n=11-12$ ). Each group had equal numbers of animals representative of each treatment regimen (treatments $1-6, n=1-2$ ), which were balanced for liveweight with an overall mean \pm SEM of $40.6 \pm 0.2 \mathrm{~kg}$. Treatment schedules were staggered I day between consecutive groups to restrict the number of does undergoing laparoscopy on any one day. The deer were contained in high fenced paddocks and grazed on ryegrass-clover pastures. The does were allocated randomly into one of six treatment regimens $(n=9-10)$. Does in treatments 1,2 and 3 (prostaglandin-induced oestrus) received a single intravaginal CIDR device (type-G, $0.3 \mathrm{~g}$ progesterone; Agricultural Division, $\mathrm{CHH}$ Plastic Products Ltd, Hamilton) for 14 days from 11-15 April until 25-29 April, inclusive. Each doe was given an i.m. injection of $500 \mu \mathrm{g} \mathrm{PGF}_{2 \alpha}$ analogue, cloprostenol ( $2 \mathrm{ml}$ Estrumate; Imperial Chemical Industries, plc, Cheshire) at 06:00 h between 8 and 12 May inclusive (i.e. day 13 after CIDR device withdrawal). The does in treatments 2 and 3 received an additional i.m. injection of 50 or 100 iu pregnant mares' serum gonadotrophin (PMSG: Folligon; Chemavet, Auckland), respectively, at the time of prostaglandin injection. Does in treatments 4, 5 and 6 (CIDR device-induced oestrus) received a single CIDR device for 14 days from 24 and 28 April until 8 and 12 May, inclusive. The does in treatments 5 and 6 received an i.m. injection of 50 or $100 \mathrm{iu}$ of PMSG at the time of CIDR device withdrawal (i.e. 06:00 h 8 and 12 May, inclusive).
Detection of oestrus. The bucks were fitted with mating harnesses (Fergus; Merck, Sharpe and Dohme NZ Ltd, Auckland) containing red crayons. The crayons were replaced every 8-12 h. Does were checked for mating marks every $2 \mathrm{~h}$, for $72 \mathrm{~h}$, from the time of prostaglandin injection in treatment groups 1-3 or CIDR-device withdrawal in treatment groups 4-6.

Blood sampling. Blood samples were taken from does allocated to groups $I$ and 5 ( $n=4$ per treatment regimen) from the right external jugular vein into heparinized vacutainer tubes, three times a week from the time of CIDR device insertion for 34 days. In addition, blood samples were collected every $2 \mathrm{~h}$ for $72 \mathrm{~h}$ from prostaglandin injection or from CIDR-device withdrawal. Samples were withdrawn from the right external jugular vein via indwelling catheters (Intracath 3122; Derseret Company, UT) inserted $1-2 \mathrm{~h}$ before the onset of sampling. Catheter patency was maintained by back flushing with $2-3 \mathrm{ml}$ heparinized saline solution after each sampling. Blood samples were centrifuged at $1000 \mathrm{~g}$ for $25 \mathrm{~min}$ immediately after collection and plasma was stored at $-10^{\circ} \mathrm{C}$ until required for assay.

Assessment of ovulation time. Does within each treatment group were allocated randomly to one of two time intervals (16 or $20 \mathrm{~h}$ after oestrus) for initial ovarian examination by laparoscopy. Ovarian examination was repeated a maximum of four times, at an interval of $6 \mathrm{~h}$, or until ovulation was recorded as confirmed by the presence of corpora haemorrhagica. Does that failed to exhibit oestrus were examined by laparoscopy $72 \mathrm{~h}$ after prostaglandin injection or CIDR device withdrawal. The numbers of corpora albicantia, luteinized follicles and corpora haemorrhagica were recorded at every examination.

Laparoscopy was performed under general anaesthesia (6.0 mg ketamine hydrochloride $\mathrm{kg}^{-1}$ liveweight [Ketaset; Bristol-Meyers Co., Syracuse, NY] and $3.0 \mathrm{mg}$ xylazine hydrochloride $\mathrm{kg}^{-\mathrm{I}}$ liveweight [Rompun; Bayer, Leverkusen]) as described by Asher et al. (1990b). After laparoscopy, $10 \mathrm{ml}$ of a long-acting antibiotic (Propen LA; Glaxo NZ Ltd, Auckland) was administered by i.m. injection. Anaesthesia was reversed with an i.v. injection of $0.5 \mathrm{mg}$ yohimbine hydrochloride $\mathrm{kg}^{-1}$ liveweight (Recervyl; Aspiring Animal Services, Wanaka).

Hormone assays. Daily blood samples were assayed for progesterone, and samples collected every $2 \mathrm{~h}$ were assayed for LH. Progesterone concentrations were measured in duplicate by a radioimmunoassay validated previously for fallow deer serum (Asher, 1985). The antiserum was raised in a rabbit against progesterone-BSA conjugate and used at a final dilution of 1:3000. The only significant crossreaction of a wide range of steroids tested in the assay was cholesterol (1.5\%). Sensitivity of the standard curve was $0.03 \mathrm{ng}$ per tube $\left(0.15 \mathrm{ng} \mathrm{m}^{-1}\right)$ and the intra- and interassay coefficients of variation were $12.8 \%$ and $12.2 \%$, respectively.

Plasma LH concentrations were determined in duplicate using a heterologous radioimmunoassay procedure described for ovine plasma by Scaramuzzi et al. (1970). The assay has been validated for fallow deer plasma by Asher (1985). The ovine pituitary LH preparation used for standards and iodinated tracer 
was NIH-LH-S11. The LH antibody which was raised in a rabbit, using NIH-LH-S11 as the antigen, was used in the assay at a final dilution of 1:40 000. Crossreactivities with other proteins have been described by Kelly et al. (1982) and Asher et al. (1986). All samples from an individual animal were included within a single assay. The intra-assay coefficients of variation were $15.7 \%$ for the low control (mean concentration $=0.66 \mathrm{ng} \mathrm{ml}^{-1}$ ), $11.5 \%$ for the medium control ( $12.10 \mathrm{ng} \mathrm{ml}^{-1}$ ) and $22.0 \%$ for the high control $\left(17.68 \mathrm{ng} \mathrm{ml}^{-1}\right)$. The interassay coefficients of variation were $24.2 \%, 10.2 \%$ and $27.9 \%$, respectively, for the three control samples. The assay sensitivity, defined as the first point on the standard curve that was significantly different from 0 , was $0.03 \mathrm{ng} \mathrm{NIH-LH}-\mathrm{SII}\left(0.30 \mathrm{ng} \mathrm{m}^{-1}\right)$.

\section{Experiment 2}

Animal management and treatments. A total of 105 mature fallow deer does and four vasectomized bucks were used between April and June 1990. The animals were held in four separate groups (groups 1-4, $n=26-27$ with one buck per group). Each group had equal numbers of animals representative of each treatment regimen (treatments 1-4, $n=6-7$ ), which were balanced for liveweight with an overall mean \pm SEM of $37.2 \pm 0.2 \mathrm{~kg}$. The animals were treated with four different oestrous synchronization regimens. Does in treatments 1 and 2 (prostaglandin-induced oestrus) received a single CIDR device for 14 days from 17 April. Each doe was given an i.m. injection of $500 \mu \mathrm{g}$ cloprostenol at $06: 00 \mathrm{~h}$ on 14 May (day 13 of the oestrous cycle). The does in treatment 2 received an additional injection of 50 iu PMSG at the time of prostaglandin administration. Does in treatments 3 and 4 (CIDR-induced oestrus) received a single CIDR device for 14 days from 30 April. The does in treatment 4 received an i.m. injection of 50 iu PMSG at the time of CIDR device withdrawal (06:00 h on 14 May). All animals were inseminated cervically $12 \mathrm{~h}$ before the median time to onset of ovulation as estimated for each treatment group in Expt 1 (that is at $61,49,55$ or $49 \mathrm{~h}$ after prostaglandin administration or CIDR-device withdrawal for does treated with prostaglandin alone, prostaglandin and 50 iu PMSG, CIDR devices alone or CIDR devices and 50 iu PMSG, respectively). A total of $200 \times 10^{6}$ spermatozoa (more than $140 \times 10^{6}$ motile spermatozoa) was deposited in the os cervix using a speculum and Cassou inseminating pipettes (Livestock Improvement Centre, Hamilton). Ten days after insemination, the vasectomized bucks were replaced with intact bucks.

Semen collection. Semen was collected from seven cross-bred fallow bucks (Dama dama dama $\times$ Dama dama mesopotamica) by electroejaculation (Asher et al., 1987) under heavy sedation $(5.0 \mathrm{mg}$ ketamine hydrochloride and $2.5 \mathrm{mg}$ xylazine hydrochloride $\mathrm{kg}^{-1}$ liveweight). The bucks were treated with melatonin implants (Regulin; Schering Agrochemicals Ltd, NSW) on four occasions at 30 day intervals starting in November 1989. Ejaculates processed for freezing were collected, between March and May 1990, into pre-warmed glass vials and individually assessed for volume, density of spermatozoa and motility (Asher et al., 1988a). The semen was then extended in $2.9 \%$ sodium citrate, $20 \%$ egg yolk diluent with $8 \%$ glycerol as a cryoprotectant (Krzywinski and Jaczewski, 1978) to a total concentration of $400 \times 10^{6}$ spermatozoa ml ${ }^{-1}$. The diluted semen was cooled to $5^{\circ} \mathrm{C}$, loaded into $0.25 \mathrm{ml}$ straws, frozen in liquid nitrogen vapour to $-125^{\circ} \mathrm{C}$ in a programmable freezer $\left(6^{\circ} \mathrm{C}\right.$ per min reduction), and transferred into liquid nitrogen until required for insemination. Several days after freezing, a straw from each ejaculate was thawed in a water bath at $37^{\circ} \mathrm{C}$ and semen was assessed for post-thaw recovery rate of spermatozoa. Only ejaculates with $>70 \%$ post-thaw motility rate were used for insemination.

\section{Experiment 3}

Animal management and treatments. At total of 93 mature fallow deer does were used between April and June 1991. The animals were held in two separate groups. Each group had equal numbers of animals representative of each treatment regimen (treatments $1-3, n=10-13$ ), which were balanced for liveweight with an overall mean \pm SEM of $38.2 \pm 0.3 \mathrm{~kg}$. All does received a single CIDR device for 14 days from 13 April. After CIDR device withdrawal, the does were inseminated cervically with $50 \times 10^{6}, 25 \times 10^{6}$ or $12.5 \times 10^{6}$ fresh spermatozoa at $12 \mathrm{~h}$ before the median time to onset of ovulation (i.e. $55 \mathrm{~h}$ after CIDR device withdrawal). Ten days after insemination, an intact fallow deer buck was introduced into each group.

Semen collection. Semen was collected from a cross-bred fallow buck on the day of insemination by electroejaculation. After assessment, the semen was extended in $2.9 \%$ sodium citrate, $20 \%$ egg yolk diluent to a total concentration of $200 \times 10^{6}, 100 \times 10^{6}$ or $50 \times 10^{6}$ spermatozoa $\mathrm{ml}^{-1}$. The diluted semen was loaded into $0.25 \mathrm{ml}$ straws and kept at ambient temperature until insemination.

Pregnancy diagnosis. Conception rates in Expts 2 and 3 were determined 42-43 days after insemination by ultrasound imaging of the reproductive tracts as described by Asher $e$ t al. (1990a). Imaging was carried out using a $5 \mathrm{MHz}$ probe inserted into the rectum while the does were restrained in an upright position in a cradle. Conceptuses were classified into two distinct groups; day 42-43 (fetal crown-rump length of 15$20 \mathrm{~mm}$ ) indicating conception due to insemination and day 20 21 (fetal length more than $6 \mathrm{~mm}$ ) indicating pregnancy due to natural mating.

\section{Statistical analyses}

The data were analysed by chi-square analysis or analysis of variance (Numerical Algorythms Group Ltd, Oxford). Mean plasma LH and progesterone profiles were obtained by normalizing the data at about the time of prostaglandin administration/CIDR device withdrawal and the LH peak.

\section{Results}

\section{Experiment 1}

Oestrous behaviour. Forty-one does exhibited oestrous behaviour within $38 \mathrm{~h}$, with an overall mean ( \pm SEM) time to 
Table 1. The effect of prostaglandin and controlled internal drug release (CIDR) devices with or without 50 or 100 iu pregnant mares' serum gonadotrophin (PMSG) on oestrous behaviour and the ovulatory response in fallow deer (values in parentheses are ranges of time to onset of oestrus or ovulation)

\begin{tabular}{|c|c|c|c|c|}
\hline Treatment & $\begin{array}{c}\text { Incidence } \\
\text { of } \\
\text { oestrus }\end{array}$ & $\begin{array}{l}\text { Time to onset } \\
\text { of oestrus } \\
\text { (h) }\end{array}$ & $\begin{array}{c}\text { Incidence } \\
\text { of } \\
\text { ovulation }\end{array}$ & $\begin{array}{l}\text { Median time to } \\
\text { onset of ovulation } \\
\text { (h) }\end{array}$ \\
\hline Prostaglandin alone & $7 / 10$ & $\begin{array}{c}47.1 \pm 2.9 \\
(42-64)\end{array}$ & $8 / 10$ & $\begin{array}{c}26 \\
(22-28)\end{array}$ \\
\hline Prostaglandin + 50 iu PMSG & $4 / 9$ & $\begin{array}{c}33.5 \pm 1.7 \\
(30-38)\end{array}$ & $5 / 9$ & $\begin{array}{c}28 \\
(22-32)\end{array}$ \\
\hline Prostaglandin +100 iu PMSG & $1 / 10$ & 44.0 & $5 / 10$ & 28 \\
\hline CIDR devices alone & $10 / 10$ & $\begin{array}{c}43.0 \pm 3.6 \\
(26-62)\end{array}$ & $9 / 10$ & $\begin{array}{c}24 \\
(22-28)\end{array}$ \\
\hline CIDR devices +50 iu PMSG & $9 / 10$ & $\begin{array}{c}35.1 \pm 1.3 \\
(28-42)\end{array}$ & $10 / 10$ & $\begin{array}{c}26 \\
(22-28)\end{array}$ \\
\hline CIDR devices + 100 iu PMSG & $10 / 10$ & $\begin{array}{c}33.6 \pm 1.7 \\
(28-42)\end{array}$ & $7 / 10$ & $\begin{array}{c}26 \\
(20-28)\end{array}$ \\
\hline Total & $41 / 59$ & $\begin{array}{c}38.8 \pm 1.4 \\
(26-64)\end{array}$ & $44 / 59$ & $\begin{array}{c}26 \\
(20-32)\end{array}$ \\
\hline
\end{tabular}

onset of oestrus of $38.1 \pm 1.4 \mathrm{~h}$ after prostaglandin administration or CIDR device withdrawal (Table 1 ). The oestrous synchronization treatment had a significant effect on the proportion of does that displayed oestrous behaviour (Table 1, $P<0.001)$. Treatment with CIDR devices resulted in a higher proportion of does displaying oestrus than was obtained following prostaglandin treatment $(29$ of 30 versus 12 of 29 , $P<0.001)$. Moreover, the incidence of oestrus declined with increasing doses of PMSG ( 17 of 20,13 of 19 and 11 of 20 following treatment with 0,50 or 100 iu PMSG, respectively, $P<0.05$ ).

The inclusion of PMSG in the oestrous synchronization regimen had a significant linear effect on the time to onset of oestrus (Table $1, P<0.01$ ). The does treated with PMSG displayed oestrus earlier, at a mean ( \pm SEM) of $34.6 \pm 0.9 \mathrm{~h}$ compared with $44.7 \pm 2.4 \mathrm{~h}$ for does treated with prostaglandin or CIDR devices alone $(P<0.05)$. Moreover, treatment with PMSG reduced the range of the time to onset of oestrus from 22 to $8 \mathrm{~h}$ for does treated with prostaglandin and from 36 to $14 \mathrm{~h}$ for does treated with CIDR devices.

Endocrine response. There was no increase in plasma $\mathrm{LH}$ concentration before $24 \mathrm{~h}$ after the end of the oestrous synchronization treatment. The number of $\mathrm{LH}$ surges was higher following treatment with CIDR devices than with prostaglandin (10 of 12 versus 3 of $12, P<0.01$ ). PMSG treatment had no effect on the mean peak LH concentration $\left(30.5 \pm 4.4\right.$ versus $32.6 \pm 2.2 \mathrm{ng} \mathrm{ml}^{-1}$ for does treated with or without PMSG, respectively) or the mean time to LH peak $(42.4 \pm 2.0$ versus $49.5 \pm 5.5 \mathrm{~h}$ for does treated with or without PMSG, respectively). The overall mean peak LH concentration and mean time to $\mathrm{LH}$ peak were $30.2 \pm 3.4 \mathrm{ng} \mathrm{ml}^{-1}$ and $45.2 \pm 2.2 \mathrm{~h}$ after prostaglandin administration or CIDR device withdrawal.
Ten of the thirteen does that had an LH surge following treatment with prostaglandin or CIDR devices had ovulated (prostaglandin, $n=2$; CIDR devices, $n=8$ ). The other three does had luteinized follicles. Of the eleven does that failed to show an increase in LH concentration, seven (prostaglandin, $n=5$; CIDR devices, $n=2$ ) had several medium sized follicles. The other four does, which were treated with prostaglandin and $50 \mathrm{iu}(n=2)$ or $100 \mathrm{iu}(n=2)$ PMSG, had ovulation points.

Plasma progesterone concentrations increased to $4.1 \pm 0.4$ and $5.6 \pm 0.7 \mathrm{ng} \mathrm{ml}^{-1}$ following CIDR device insertion and declined to $0.07 \pm 0.02$ and $0.3 \pm 0.07 \mathrm{ng} \mathrm{ml}^{-1}$ following CIDR device withdrawal for does synchronized with prostaglandin or CIDR devices, respectively (Fig. 1). For does synchronized with prostaglandin there was a slight increase in plasma progesterone concentration following CIDR device withdrawal and by day 13 (time of prostaglandin administration) mean \pm SEM progesterone concentration was $1.5 \pm 0.4 \mathrm{ng} \mathrm{ml}^{-1}$. After prostaglandin administration, progesterone concentrations remained below $1 \mathrm{ng} \mathrm{ml}^{-1}$ for non-ovulatory does $(n=6)$. However, does that had ovulated $(n=6)$ showed a slow and gradual increase in progesterone concentration. For does synchronized with CIDR devices, plasma progesterone concentrations increased to more than $1 \mathrm{ng} \mathrm{ml}{ }^{-1}$ and declined to $0.08 \pm 0.01 \mathrm{ng} \mathrm{ml}^{-1}$ by days 10 and 27 after CIDR device withdrawal, respectively.

Ovulatory response. Forty-four does had ovulated by $72 \mathrm{~h}$ after prostaglandin administration or CIDR device withdrawal. Of the 41 does that displayed oestrous behaviour, 35 does had ovulated during the repeated laparoscopy schedule. The other six does had either one $(n=3)$ or two $(n=1)$ luteinized follicles or one $(n=2)$ small atretic follicle at the final laparoscopic inspection. The oestrous synchronization regimen had no effect on the timing of ovulation. The overall median time to onset of 


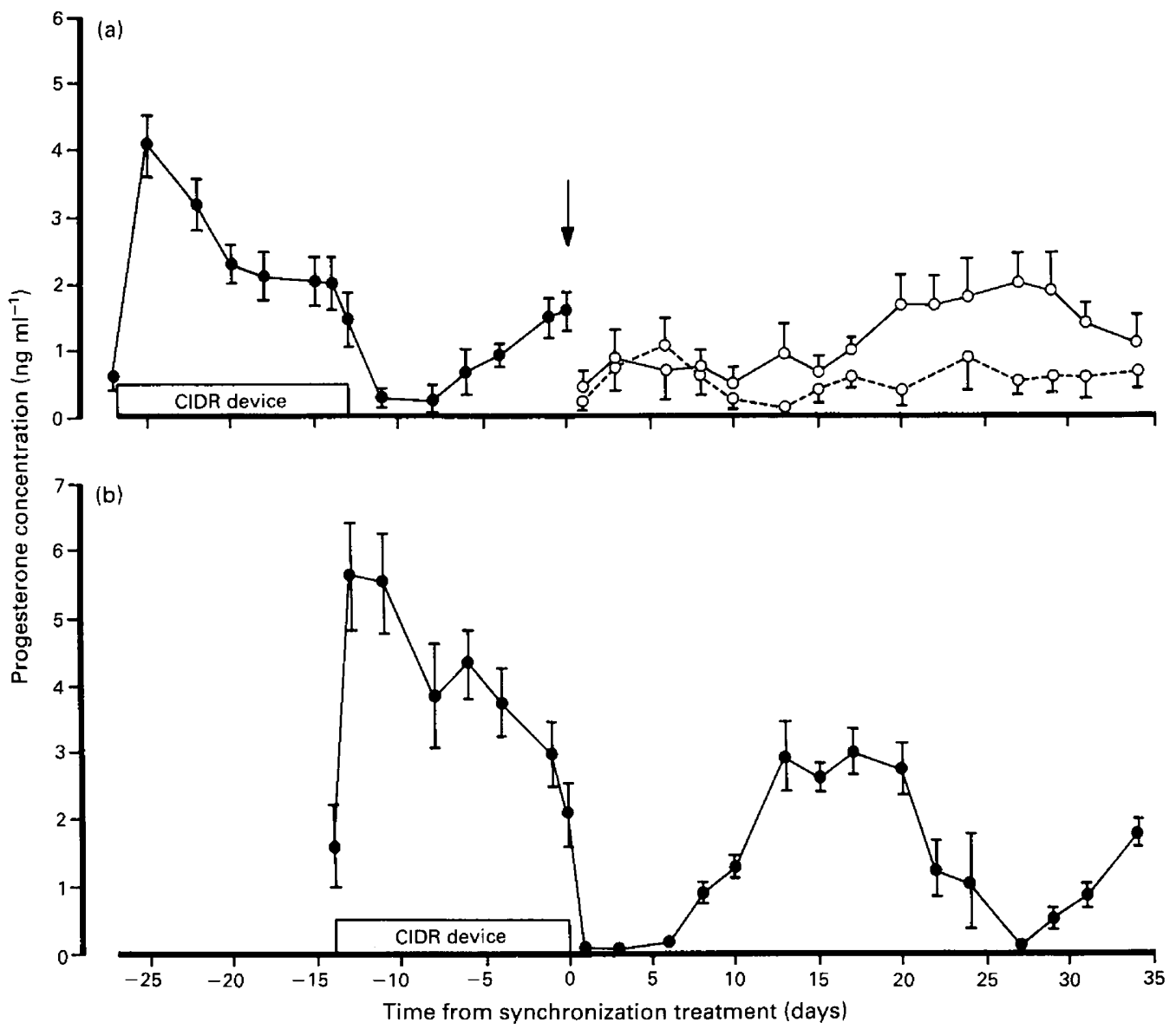

Fig. 1. Profiles of mean ( \pm SEM) plasma progesterone concentrations of fallow deer during and after different treatment regimens designed to synchronize oestrus. (a) Profiles of ovulating $(\bigcirc-O, n=6)$ and nonovulating $(O---O, n=6)$ does following initial 14-day controlled internal drug release (CIDR)-device treatment followed by an i.m. injection of prostaglandin analogue (arrow) on day 13 of the subsequent cycle. (b) Profile of does treated with CIDR devices $(n=12)$ for a period of 14 days.

ovulation was $26 \mathrm{~h}$ after the onset of oestrus (Table 1 ). The does in each treatment group ovulated within 6-10 h of each other. None of the animals had ovulated by $16 \mathrm{~h}$ and of the 35 does, numbers ovulating at 16-20, 20-22, 22-26, 26-28 and $28-32 \mathrm{~h}$ were, respectively, $3(8.6 \%), 9(25.7 \%), 13(37.1 \%), 9(25.7 \%)$ and $I(2.9 \%)$.

Of the does treated with prostaglandin or CIDR devices alone, 8 of 10 and 9 of 10 had a corpus luteum, respectively (Table 1). Each of the remaining three does had one small atretic follicle. The administration of 50 iu or 100 iu PMSG to prostaglandin-treated does stimulated the incidence of single $(n=7)$ or twin $(n=2)$ luteinized follicles that failed to ovulate and twin corpora lutea $(n=2)$. However, only the administration of 100 iu PMSG to does treated with CIDR devices stimulated the incidence of luteinized follicles (single, $n=2$; twin, $n=1$ ) and twin corpora lutea $(n=2)$.

\section{Experiment 2}

The proportion of pregnant does was higher following treatment with CIDR devices than following prostaglandin (38 of 52 versus 28 of $53, P<0.05$ ). There was a significant interaction between the method of oestrous synchronization and PMSG treatment $(P<0.01)$. The administration of 50 iu PMSG was beneficial only for does treated with prostaglandin (Table 2).

\section{Experiment 3}

The overall conception rate following cervical insemination with fresh spermatozoa at $55 \mathrm{~h}$ after CIDR device withdrawal was $76.3 \%$. The concentration of spermatozoa deposited in the os cervix had no effect on conception rate (Table 3 ).

\section{Discussion}

Early in the breeding season, CIDR devices are more reliable than prostaglandin for the synchronization of oestrus. In the present study, initial oestrous synchronization of prostaglandintreated does was performed with CIDR devices that may have been inserted relatively early in relation to the onset of the rut. 
Table 2. The effect of prostaglandin or controlled internal drug release (CIDR) devices with or without 50 iu pregnant mares' serum gonadotrophin (PMSG) on conception rates in fallow deer following cervical insemination with $200 \times 10^{6}$ frozen-thawed spermatozoa

\begin{tabular}{lccc}
\hline Treatment & $\begin{array}{c}\text { Number of does } \\
\text { inseminated }\end{array}$ & $\begin{array}{c}\text { Number of does } \\
\text { pregnant }\end{array}$ & $\begin{array}{c}\text { Conception } \\
\text { rate (\%) }\end{array}$ \\
\hline $\begin{array}{l}\text { Prostaglandin alone } \\
\text { Prostaglandin+ }\end{array} \quad 27$ & 11 & 40.7 \\
$\quad 50$ iu PMSG & 26 & 17 & 65.4 \\
CIDR devices alone & 26 & 22 & 84.5 \\
$\begin{array}{l}\text { CIDR devices+ } \\
\text { 50 iu PMSG }\end{array}$ & 26 & 16 & 61.5 \\
\begin{tabular}{l} 
Total \\
\hline
\end{tabular} & 105 & 66 & 62.9 \\
\hline
\end{tabular}

Table 3. The effect of the concentration of fresh spermatozoa on conception rate in fallow deer following cervical insemination

\begin{tabular}{lccc}
\hline $\begin{array}{l}\text { Concentration } \\
\text { of spermatozoa }\end{array}$ & $\begin{array}{c}\text { Number of } \\
\text { does } \\
\text { inseminated }\end{array}$ & $\begin{array}{c}\text { Number of } \\
\text { does } \\
\text { pregnant }\end{array}$ & $\begin{array}{c}\text { Conception } \\
\text { rate } \\
(\%)\end{array}$ \\
\hline $50 \times 10^{6}$ & 32 & 26 & 81.2 \\
$25 \times 10^{6}$ & 30 & 20 & 66.6 \\
$12.5 \times 10^{6}$ & 31 & 25 & 80.6 \\
Total & 93 & 71 & 76.3 \\
\hline
\end{tabular}

This is in agreement with the finding that CIDR-device withdrawal just before the onset of the natural rut results in low incidence of oestrus. However, the proportion of does exhibiting oestrus increases and the mean interval between CIDRdevice withdrawal and onset of oestrus progressively decreases as CIDR devices are removed progressively later relative to the occurrence of first spontaneous oestrus within the herd (Morrow et al., 1992). It must be stressed that the use of CIDR devices is not a pre-requisite for the success of the prostaglandin regimen. However, the limited data available show that the corpus luteum is sensitive to the luteolytic effect of progesterone on day 13 of the oestrous cycle (Asher and Thompson, 1989); pretreatment with progesterone is therefore necessary to ensure that the luteolytic agent is administered at an appropriate time. Future work is needed to determine the sensitivity of the corpus luteum to prostaglandin at all stages of the oestrous cycle. This information may help determine a suitable interval between a double prostaglandin regimen that can be applied after the onset of the natural rut. This will ultimately reduce the duration of the oestrous synchronization regimen and may improve the oestrous and ovulatory responses of fallow deer to prostaglandin.

The administration of 50 or $100 \mathrm{iu}$ PMSG at the time of prostaglandin administration or CIDR-device withdrawal advanced the time to onset and improved the synchrony of oestrus and ovulation. This may be attributed to rapid follicular maturation and enhanced oestrogen secretion by follicles following stimulation with PMSG. However, the interval between the time of ovulation and the onset of oestrus remained constant. The overall median time to ovulation was $26 \mathrm{~h}$ after the onset of oestrus. This result confirms the observations of Asher et al. (1990b) who reported that the interval from the onset of oestrus to ovulation was less variable than that from the end of synchronization treatment to oestrus or ovulation following treatment with prostaglandin or CIDR devices alone. PMSG at doses of $500 \mathrm{iu}$ (Asher and Smith, 1987) or $200 \mathrm{iu}$ (G. W. Asher, unpublished data) have previously been used in fallow deer. However, multiple ovulations or complete failure of ovulation was observed in a proportion of treated animals. This ultimately reduced conception rates and increased the incidence of embryonic mortality. In the present study, the administration of 100 iu PMSG stimulated twin ovulations and the administration of 100 iu or 50 iu PMSG stimulated premature luteinization of follicles. This attests to the high sensitivity of fallow deer to the exogenous gonadotrophin and mitigates against the general use of PMSG in oestrous synchronization programmes. In sheep (Colas et al., 1973) and red deer (Fennessy et al., 1989) 375 iu and 200 iu PMSG, respectively, are used to improve the synchrony of oestrus and ovulation and ultimately fertility. In red deer, this procedure has occasionally resulted in conception and births of twins in artificial insemination programmes (Asher et al., 1988b); however, there is little evidence of production losses through reduced fertility and increased embryonic loss.

The low incidence of an LH surge in prostaglandin-treated animals may be attributed to the fact that treatment in those does was applied relatively early in relation to the onset of the natural rut. This is supported by the relatively low concentrations of plasma progesterone observed following CIDR device withdrawal and the low incidence of ovulation observed in those does as well. However, four females treated with prostaglandin and PMSG had ovulation points, although no increase in LH concentrations was detected in those animals. This may be a result of direct action of PMSG at the ovarian level to cause ovulation (Cameron and Batt, 1991). This contention is further supported by the incidence of premature luteinizaton of follicles observed in three does treated with PMSG and which lacked a LH surge.

Previous attempts at cervical insemination have resulted in moderate fawning rates (approximately 50\%) following the deposition of $85 \times 10^{6}$ motile fresh or frozen-thawed 
spermatozoa at $48 \mathrm{~h}$ after CIDR device withdrawal (Asher et al., 1988a). The reasons for the improved fertility observed in this study are not clear. It is possibly a consequence of the higher concentration of deposited spermatozoa or insemination closer to the time of ovulation or of both factors. It is noteworthy that comparable conception rates can be achieved following cervical and uterine insemination even with concentrations of spermatozoa as low as $12.5 \times 10^{6}$. Asher et al. (1992) reported conception rates of $81 \%$ and $78 \%$ following intrauterine insemination with $7.5 \times 10^{6}$ fresh and $25 \times 10^{6}$ frozen-thawed spermatozoa, respectively. In red deer, intrauterine insemination is more effective than single per vaginum insemination (Fennessy et al., 1990).

Artificial insemination following treatment with CIDR devices resulted in higher conception rates than following treatment with prostaglandin. Similar results have been reported in sheep (Lightfoot et al., 1976; Boland et al., 1978). This may be attributed to the lower efficiency of prostaglandin to synchronize oestrus, particularly when treatment is applied early in the breeding season; and to reduce efficiency of sperm transport in the reproductive tract possibly owing to the effect of prostaglandin on uterine motility (Hawk, 1973). The administration of 50 iu PMSG reduced conception rates following oestrous synchronization with CIDR devices. The reasons for this are not clear; as oestrous and ovulation synchrony is improved following the administration of the gonadotrophin, it would be expected that fertility following fixed-time insemination would also improve. It is possible that PMSG, even at such low doses, altered the rate of gamete transport through the reproductive tract (Robinson, 1951). Ova arriving prematurely in the uterus may degenerate and are promptly expelled from the uterus via the cervix (Whyman and Moore, 1980).

In conclusion, this study has demonstrated that early in the breeding season CIDR devices are more suitable than prostaglandin for oestrous synchronization. Although the administration of 50 iu PMSG at the time of prostaglandin administration/CIDR-device withdrawal improves the synchrony of oestrus and ovulation, conception rates are generally reduced following the administration of the gonadotrophin in artificial insemination programmes. High conception rates can be achieved following cervical insemination of fallow deer with as low as $12.5 \times 10^{6}$ fresh spermatozoa $12 \mathrm{~h}$ before the median time of ovulation.

The authors would like to thank R. French and I. Morrisson for providing animals for the trials and $\mathrm{M}$. Langridge, G. Shackell and I. Scott for invaluable technical assistance.

\section{References}

Adam CL, Moir CE and Atkinson T (1985) Plasma concentrations of progesterone in female red deer (Cervus elaphus) during the breeding season, pregnancy and anoestrus Journal of Reproduction and Fertility 74 631-636

Asher GW (1985) Oestrous cycle and breeding season of farmed fallow deer, Dama dama Joumal of Reproduction and Fertility 75 521-529

Asher GW and Smith JF (1987) Induction of oestrus and ovulation in farmed fallow deer (Dama dama) by using progesterone and PMSG treatment Journal of Reproduction and Fertility 81 113-118
Asher GW and Thompson JGE (1989) Plasma progesterone and LH concentrations during oestrous synchronization in female fallow deer (Dama dama) Animal Reproduction Science 19 143-153

Asher GW, Barrell GK and Peterson AJ (1986) Hormonal changes around oestrus of farmed fallow deer, Dama dama Joumal of Reproduction and Fertility 78 487-496

Asher GW, Day AM and Barrell GK (1987) Annual cycle of liveweight and reproductive changes of farmed male fallow deer (Dama dama) and the effect of daily oral administration of melatonin in summer on the attainment of seasonal fertility Journal of Reproduction and Fertility 79 353-362

Asher GW, Adam JL, James RW and Barnes D (1988a) Artificial insemination of farmed fallow deer (Dama dama): fixed-time insemination at a synchronised oestrus. Animal Production 47 487-492

Asher GW, Adam JL, Otway W, Bowmar P, Van Reenan G, Mackintosh CG and Dratch P (1988b) Hybridization of Père David's deer (Elaphurus davidianus) and red deer (Cervus elaphus) by artificial insemination Joumal of Zoology (London) 215 197-203

Asher GW, Kraemer DC, Magyar SJ, Brunner M, Moerbe R and Giaquinto M (1990a) Intrauterine insemination of farmed fallow deer (Dama dama) with frozen-thawed semen via laparoscopy Theriogenology 34 569-577

Asher GW, Fisher MW, Smith JF, Jabbour HN and Morrow CJ (1990b) Temporal relationship between the onset of oestrus, the pre-ovulatory LH surge and ovulation in farmed fallow deer, Dama dama Journal of Reproduction and Fertility 89 761-767

Asher GW, Morrow CJ, Jabbour HN, Mulley RC, Veldhuizen FA and Langridge M (1992) Laparoscopic intra-uterine insemination of fallow deer with frozenthawed or fresh spermatozoa after synchronisation with CIDR devices New Zealand Veterinary Journal 40 8-14

Boland MP, Gordon I and Kelleher DL (1978) The effect of treatment by prostaglandin analogue (ICI 80,996) or progestagen (SC-9880) on ovulation and fertilisation in cyclic ewes Journal of Agricultural Science (Cambridge) 91 $727-730$

Cameron AWN and Batt PA (1991) PMSG may directly stimulate ovulation in goats Animal Reproduction Science 25 233-239

Colas G, Thimonier J, Courot M and Ortavant R (1973) Fertility, prolificacy and fecundity during the breeding season of ewes artificially inseminated after treatment with fluorogestone acetate Annals de Zootechnie 33 441-451

Fennessy PF, Fisher MW and Asher GW (1989) Synchronisation of the oestrous cycle in deer Proceedings of a deer course for Veterinarians; Deer Branch (NZVA) Course No. 6, 29-35

Fennessy PF, Mackintosh CG and Shackell GH (1990) Artificial insemination of farmed red deer (Cervus elaphus) Animal Production $51613-621$

Glover GJ (1985) Aspects of reproductive physiology of female wapiti. MSc Thesis, University of Saskatchewan, Saskatoon, Canada

Hawk HW (1973) Uterine motility and sperm transport in the oestrous ewe after prostaglandin induced regression of corpora lutea Joumal of Animal Science 37 1380-1385

Kelly RW, McNatty KP, Moore GH, Ross D and Gibb M (1982) Plasma concentrations of $\mathrm{LH}$, prolactin, oestradiol and progesterone in female red deer (Cervus elaphus) during pregnancy Journal of Reproduction and Fertility 64 $475-483$

Krzywinski A and Jaczewski Z (1978) Observations on the artificial breeding of red deer Symposium of the Zoological Society of London 43 271-287

Lightfoot RJ, Croker KP and Marshall T (1976) Use of prostaglandin analogue (ICI 80,996) for the synchronisation of oestrus and lambing in Merino ewes. In Proceedings of the International Sheep Breeding Congress pp 449-454 Eds GJ Tomes, DE Robertson and RJ Lightfoot. Muresk, Perth

Maxwell WMC (1984) Current problems and future potential of artificial insemination programmes. In Reproduction in Sheep Pp 291-298 Eds DR Lindsay and DT Pearce. Australian Academy of Science and Australian Wool Corporation, Canberra

Morrow CJ, Asher GW, Smith JF, Jabbour HN, Mulley RC and McLeay LM (1992) Seasonal effects on the efficacy of intravaginal CIDR devices for oestrous synchronisation of farmed fallow deer (Dama dama) Proceedings of the New Zealand Society of Animal Production 52 165 -169

Mulley RC, Moore NW and English AW (1988) Successful uterine insemination of fallow deer with fresh and frozen semen Theriogenology 29 1149-1153

Mylrea GE, English AW, Mulley RC and Evans G (1990) Artificial insemination of farmed chital deer. In The Biology of Deer pp 334-337. Ed. RD Brown. Springer Verlag, New York 
Robinson 'TJ (1951) The control of fertility in sheep. Part II. The augmentation of fertility of gonadotrophin treatment of the ewe in the normal breeding season Joumal of Agricultural Science (Cambridge) 41 6-63

Scaramuzzi RJ, Caldwell BV and Moor RM (1970) Radioimmunoassay of LH and oestrogen during the oestrous cycle of the ewe Biology of Reproduction 3 110-119
Whyman D and Moore RW (1980) Effects of PMSG and the prostaglandin $\mathrm{F}_{20}$ analogue, cloprostenol, on superovulation, fertilization and egg transport in the ewe Joumal of Reproduction and Fertility 60 267-272 